\title{
The Quality Management Assistance Of Financial Governance On Ud "Dua Putra" Rice Mill Business In Kutorenon Sukodono
}

\author{
Ainun Jariah \\ STIE Widya Gama Lumajang \\ anjar040820@gmail.com
}

\begin{tabular}{lll}
\hline Submission : & Review : & Publication : \\
$1^{\text {st }}$ January 2020 & $13^{\text {th }}$ January 2020 & $28^{\text {th }}$ February 2020 \\
\hline
\end{tabular}

\begin{abstract}
Abstrak
The activity aims to provide quality management assistance of financial governance on UD "DUA PUTRA" rice mill business in Kutorenon Sukodono, so that the company is able to improve the human resources ability in managing its business management; strengthen the human resources ability in the preparation of bookkeeping regularly and correctly; improve the ability to separate between business and household finances; find easy capital access. The method used in this community service activity has several stages, including initial surveys, interviews in order to find offered problems and solutions, business management assistance, financial management and UKM operational funding assistance. The weakness of partner mainly lies in the limited human resources ability in manage their business, the unavalaibility of human resources who understand business bookkeeping regularly, unseparated business and household finances and limited capital access. Targets to be achieved, include: increase partner skills in running its business sustainably; strengthening the ability of partners in the preparation of bookkeeping regularly and correctly; increasing the ability of partners in separating business and household finances and obtaining easy capital access.
\end{abstract}

\section{Keywords: Rice, UD “DUA PUTRA”, Business, Financial, Capital.}

\section{INTRODUCTION}

Paddy, which is processed into rice and cooked into rice cannot be separated from Indonesian livelihoods. Rice comes from India, which spread to number of regions and finally reached to Nusantara. In $15^{\text {th }}$ century, rice has become the preffered crop because it can grow well, wrote Anthony Reid in "Asia Tenggara Kurun Niaga 1450-1680". Rice has been traded when Dutch East Indies Company (VOC) began their journey in Dutch East Indies. Besides Java, the production of rice appeared in Lombok, South Sulawesi and Sumbawa. The rice production was increased during colonials, and even exported it to Netherlands and South Asia countries. However, rice is not yet a staple food.

According to A.M..P.A Scheltema, the Dutch East Indies Bureau of Statistics officials who oversee Natives Farming said that some people still view rice as the main trade commodity. So, even though there is a large amount of rice production in certain districts, the local residents prefer to choose cheaper food sources such as maize and cassava and sell the rice they produce. In addition, the customary factors affect food consumption. Someone considers the most delicious food is the food that has been loved since their ancestors.

"It can be said that rice is not yet a staple food to most natives, at least until first half of $19^{\text {th }}$ century, and eating rice has become increasingly important in the last hundred years as a result of massive rice fields expansion," wrote A.M.P.A Scheltema in "Konsumsi Pangan 
Penduduk Pribumi di Jawa dan Madura", published in Sejarah Statistik Ekonomi Indonesia edited by Pieter Creutzberg and J.T.M van Laanen. Although the rice fields increased, the rice production has not improved due to crop failure. The crop failure encourages people to turn away from rice. Until the end of colonials, efforts to increase rice production were still successful. Meanwhile, the rice consumption keep increasing. Now, most of Indonesian people are eating rice. The attachment on rice then become a problem when the rice production decreased. History records, from the era of Soekarno to Soeharto, the government were tried hard to boost rice production and along with it, they launched a food diversification program.

One of the rice mill businesses that well known by many people is UD "DUA PUTRA". Although the business located in the village, it is not less than other rice mills business. Even though it is relatively young, this business has been able to serve rice demand to some regions include Lumajang, Jember and Bondowoso. Same as other businesses, UD "DUA PUTRA" also have ups and downs, but it still survive to serve demand from the surrounding community and other marketing areas. Initially, UD "DUA PUTRA" are only served local residents who were lazy to travel long distances because they had to go to Bondoyudo village, moreover they had minimal vehicles. Finally, with the intiative of UD "DUA PUTRA" serving surround community, they can grow and able to survive until now.

From this reason, there was an interest in partnering with UD "DUA PUTRA" which is located in Dusun Biting 1 RT 01 RW 09 Kutorenon, Sukodono sub-district, Lumajang regency that founded by Mr. Abdul Malik since 2001. The business is able to survive until now because the owner is friendly.

The targets in this activity is UD "DUA PUTRA" rice mill business in Kutorenon village, Sukodono sub-district, Lumajang regency. The rice mill business have weaknesses include : (1) The limited human resources ability in managing their business, (2) The unavalaibility of human resources who understand business bookkeeping regularly, (3) Unseparated business and household finances, (4) Limited capital access.

These weaknesses are the basis of consideration the implementation of community service activity in management assistance to increase the quality of business financial governance.

Based on early survey and situation analysis that has been done, the group has problems as follows : (1) Limited human resources ability in managing its business, (2) Weak human resources in the preparation of business bookkeeping regularly, (3) Limited human resources ability in separate business and household finances, (4) Limited capital access.

Furthermore, formal discussions with the business partner showed agreements that the partner wanted to expand its business, regularly and correctly preparation of bookkeeping, separate business and household finances also having easy capital access.

The solutions offered in this activity as follows: (1) Increase partner's skills in managing its business, (2) Strengthening the ability of partners in the preparation of bookkeeping regularly and correctly, (3) Increasing the ability of partners in separating business and household finances, (4) Obtaining easy capital access.

This community service activitiy is expected to achieve target in accordance with the expectations of partner group, as follows : (1) Increase partner's skills in running its business sustainably, (2) Strengthening the ability of partners in the preparation of bookkeeping regularly and correctly, (3) Increasing the ability of partners in separating business and household finances, (4) Obtaining easy capital access. 


\section{IMPLEMENTATION METHODS}

The implementation methods carried out through following steps : Implementation methods carried out through following steps : (1) The interview method include : activity identity, capital, partner problems, (2) Assistance method is done by assistance and giving insight about partners skill improvement in running their business sustainably, strengthening the ability of partners in the preparation of bookkeeping regularly and correctly, increasing the ability of partners in separating business and household finances and obtaining easy capital access, (3) Funding Method the assistance was given to UD "DUA PUTRA" in the form of funds to support operational costs of IDR 500,000.

\section{RESULTS AND DISCUSSION}

\section{A. Interview Results}

UD "DUA PUTRA" is a rice mill business founded by Mr. Abdul Malik since 2001. Although UD "DUA PUTRA" has been operating for a long time and able to serve customer requests out of town, namely Jember and Bondowoso, it has not been able to manage its business, the unavalaibility of human resources who understand business bookkeeping regularly, unseparated business and household finances and limited capital access.

\section{Partner Problems}

The partner problems as follows :

(1) Limited human resources ability in managing its business.

(2) Weak human resources in the preparation of business bookkeeping regularly.

(3) Limited human resources ability in separate business and household finances.

(4) Limited capital access.

\section{B. Assistance}

The partner passion in expand its business should be appreciated. On 25 to 206 April 2020, at Dusun Biting 1 RT 01 RW 09 Kutorenon, Sukodono sub-district, implementing business management assistance, production management, financial management, marketing management, monitoring and evaluation.

\section{Funding}

The assistance was given to UD "DUA PUTRA" in the form of funds to support operational costs of IDR 500,000.

\section{CONCLUSION}

Several things can be concluded in implementation of business management assistance and financial governance quality improvement on UD "DUA PUTRA" in Dusun Biting 1 RT 01 RW 09 Kutorenon, Sukodono sub-district, Lumajang regency as follows :

a. UD "DUA PUTRA" has a strong desire to expand its business considering similar business competition that quite sharp in Lumajang. The limitations in managing business financial and limitations in separating between business and household finances.

b. This implemented community service acitivity are able to provide simple solutions to expand partner business sustainably and have competitiveness.

c. The achieved targets which is the measure of success of this community service activity is (1) increase partner skills in running its business sustainably, (2) increase the ability of partners in the preparation of bookkeeping regularly and correctly, (3) increasing the 
ability of partners in separating business and household finances, (4) obtaining easy capital access.

d. This community service activity can achieved outputs in accordance with partner expectation, namely (1) skilled human resources in running its business, (2) partner skills in preparation of bookkeeping regularly and correctly, (3) business financial management regularly and correctly, (4) obtaining easy capital access.

The toughest challenge for partners is actually when they are truly facing this business competition. Therefore, several recommendations are suggested so this activity can provide sustainable advantages, as follows :

a. The partners must have high passion and will to expand themselves by equipping themselves with increased skills both in ability to innovate and management skills.

b. The competition that quite tough must be balanced with a positive mentally and attitude, because if the program partner does not have a strong entreprenurship spirit and ability to innovate, they will be easily crushed by the level of similar business competition.

c. The intensive assistance and supervision to the program partner need to be done periodically and not stop until the completion of this program, therefore the activeness of the team and the ranks of STIE Widya Gama Lumajang community in providing guidance to this partner needs to be carried out continuously.

d. It is hoped that the further funding for this activity needs to be implemented to help other similar small businesses so that they are able to innovate and be able develop themselves in increasingly sharp business competition and be able to create jobs for the surround community.

\section{REFERENCES}

https://historia.id/kultur/articles/sehidup-semati-bersama-nasi-6aek0, accessed on April 27, 2020. 